\author{
JÓZEF JAGIEŁA \\ ORCID: 0000-0001-9103-5185 \\ Uniwersytet Łódzki
}

\title{
PRZEWINIENIA DYSCYPLINARNE KOMORNIKÓW
}

\begin{abstract}
Abstrakt: Przewinienia dyscyplinarne komorników są wymienione w art. 222 ustawy z 22 marca 2018 roku o komornikach sądowych (Dz.U. z 2020 r. poz. 121 ze zm.) w sposób wyczerpujący. $\mathrm{W}$ artykule została poddana analizie kwestia, czy katalog zawinionych działań i zaniechań komornika wymienionych w tym przepisie, a za które może być pociągnięty do odpowiedzialności dyscyplinarnej, ma charakter zamknięty czy otwarty. W tym celu przeanalizowane zostały poszczególne przewinienia dyscyplinarne wymienione w art. 222 ustawy o komornikach sądowych. Dokonane ustalenia prowadzą do wniosku, że mimo wyczerpującego wyliczenia przewinień dyscyplinarnych, katalog działań i zaniechań, za które komornik może odpowiadać dyscyplinarnie, nie jest zamknięty. Nie zostały bowiem jednoznacznie sprecyzowane czyny komornika, które mogą być uznane za przewinienia dyscyplinarne.
\end{abstract}

Słowa kluczowe: przewinienie dyscyplinarne, katalog przewinień dyscyplinarnych, uchybienie zasadom etyki zawodowej komornika, naruszenie przepisów prawa, rażąca lub uporczywa obraza przepisów prawa

Przewinienia, za które komornik może być pociągnięty do odpowiedzialności dyscyplinarnej, są określone w art. 222 ustawy z 28 marca 2018 roku o komornikach sądowych ${ }^{1}$. Zamieszczone w tym przepisie wskazanie deliktów dyscyplinarnych, w przeciwieństwie do poprzednio obowiązującej regulacji zawartej w art. 71 ustawy z 29 sierpnia 1997 roku o komornikach sądowych i egzekucji ${ }^{2}$, ma charakter wyczerpujący, a nie tylko przykładowy. Wynika to z tego, że w preambule art. 222 u.k.s., przed określeniem poszczególnych deliktów dyscyplinarnych, ustawodawca posłużył się zwrotem „za następujące”, a nie „w szczególności za”, jak miało to miejsce we wspomnianym art. 71 u.k.s.e. Prowadzi to do wniosku, że katalog przewinień dyscyplinarnych komorników ma w założeniu charakter

1 Dz.U. z 2020 r. poz. 121 ze zm., dalej: u.k.s.

2 Dz.U. z 2017 r. poz. 1277 ze zm., dalej: u.k.s.c. 
wyczerpujący, „zamknięty”3, można więc stwierdzić, że uregulowanie art. 222 u.k.s. spełnia już od dość dawna zgłaszane w tym względzie postulaty doktryny ${ }^{4}$. Zamknięty katalog przewinień dyscyplinarnych ma realizować standardy cechujące postępowania dyscyplinarne zbliżone w swoich założeniach do odpowiedzialności karnej, w ramach których mogą być stosowane wobec obwinionego określone sankcje, niekiedy bardzo dotkliwe (w przypadku komorników włącznie z wydaleniem ze służby komorniczej). Ma też usunąć wątpliwości, zaistniałe i potencjalne, wobec zakresu odpowiedzialności dyscyplinarnej komorników wyznaczonej przez art. 71 u.k.s.e. $\mathrm{Z}$ uregulowania tego przepisu wynikało, że komornik może być pociągnięty do odpowiedzialności dyscyplinarnej za każde „zawinione działania i zaniechania", a więc również inne niż naruszenie powagi i godności urzędu oraz rażącą obrazę przepisów prawa („w szczególności za”). W związku z tym w praktyce rodziły się niekiedy wątpliwości, jak należy rozumieć „winę” i do jakich działań i zaniechań komornika może być ona odnoszona jako podstawa odpowiedzialności. O ile zasadniczo nie kwestionowano, że chodzi o winę w rozumieniu prawa karnego (art. 9) ${ }^{5}$, o tyle mogły się nasuwać wątpliwości Bez tego, czyli wątpliwości, czy komornik może być pociągnięty do odpowiedzialności dyscyplinarnej za każde zawinione działanie lub zaniechanie, czy tylko za naruszenie powagi i godności urzędu oraz rażącą obrazę przepisów prawa. Dlatego też uregulowanie art. 71 u.k.s.e. wydawało się naruszać nie tylko obowiązującą na gruncie prawa karnego zasadę nullum crimen sine lege certa, która powinna mieć odpowiednie zastosowanie także w postępowaniu dyscyplinarnym komorników, ale mogło nasuwać także wątpliwości co do zgodności z Konstytucją RP i międzynarodowymi standardami ochrony praw człowieka i obywatela ${ }^{6}$.

Ponadto, jak wskazuje uzasadnienie do projektu ustawy z 28 marca 2018 roku o komornikach sądowych, w art. 222 u.k.s. rozszerzono i uporządkowano katalog deliktów dyscyplinarnych. Podkreślono przy tym wagę konieczności stosowania się przez komornika do wytycznych i zarządzeń organów nadzoru judykacyjnego oraz administracyjnego, bezwzględnego stosowania się do przepisów

${ }^{3}$ M. Klonowski, [w:] Ustawa o komornikach sadowych. Ustawa o kosztach komorniczych. Komentarz, red. R. Reiwer, Warszawa 2019, uw. 3 do art. 222; M. Świeczkowska-Wójcikowska, [w:] Ustawa o komornikach sądowych. Ustawa o kosztach komorniczych. Kodeks Etyki Zawodowej Komornika Sądowego. Komentarz, red. M. Świeczkowska-Wójcikowska, J. Świeczkowski, Warszawa 2020, uw. 4 do art. 222.

4 Zob. P. Rączka, Odpowiedzialność dyscyplinarna komornika sądowego, „Przegląd Prawa Egzekucyjnego" 2006, nr 12, s. 89 n.; G. Kuczyński, [w:] Ustawa o komornikach sadowych i egzekucji. Komentarz, red. J. Świeczkowski, Warszawa 2012, uw. 2 do art. 71; J. Jagieła, Odpowiedzialność dyscyplinarna komorników, asesorów i aplikantów komorniczych, [w:] Założenia projektu nowej ustawy o komornikach sądowych, red. A. Marciniak, Sopot 2013, s. 107.

5 Zob. między innymi Z. Knypl, Z. Merchel, Komentarz do ustawy o komornikach sadowych i egzekucji, Sopot 2013, s. 517; A. Marciniak, Ustawa o komornikach sadowych i egzekucji. Komentarz, Warszawa 2009, s. 289.

6 M. Klonowski, op. cit., Warszawa, uw. 3 do art. 222. 
o właściwości miejscowej oraz należytego sprawowania nadzoru nad zatrudnionymi asesorami i aplikantami. W związku z tym za samodzielny delikt dyscyplinarny uznano naruszenie zasad korzystania z prawa do nieobecności na służbie, usprawiedliwiania tych nieobecności i korzystania z wyznaczonego zastępcy oraz brak nadzoru nie tylko nad zatrudnionymi asesorami i aplikantami, ale i nad innymi zatrudnionymi osobami ${ }^{7}$. Nietrudno zauważyć, że niektóre z przewinień dyscyplinarnych $\mathrm{w}$ art. 222 u.k.s. zostały doprecyzowane w stosunku do poprzednio określonych $\mathrm{w}$ art. 71 u.k.s.e. albo wprowadzone jako nowe w związku z orzecznictwem komisji dyscyplinarnej, a ściślej mówiąc: w wyniku trudności z kwalifikacją niektórych czynów jako deliktów dyscyplinarnych. Uregulowania te stanowią z jednej strony ukoronowanie dorobku orzecznictwa komisji dyscyplinarnej, z drugiej zaś,poprzez zdefiniowanie poszczególnych przewinień dyscyplinarnych, mają rozwiązać problemy wiążące się z kwalifikacją niektórych działań lub zaniechań komorników jako deliktów dyscyplinarnych.

Analizując art. 222 u.k.s., nasuwa się jednak pytanie, czy wyczerpujące wyliczenie przewinień dyscyplinarnych $\mathrm{w}$ tym przepisie daje podstawy do formułowania jednoznacznej tezy, że ich katalog jest zamknięty, czyli ściśle wyznacza granice przedmiotowe odpowiedzialności dyscyplinarnej komornika albo - mówiąc inaczej - ściśle określa, za co komornik może odpowiadać dyscyplinarnie. Na pierwszy rzut oka wyliczenie zawarte w art. 222 u.k.s. wydaje się na tyle skonkretyzowane, że pozwala określić, z jakim deliktem dyscyplinarnym mamy do czynienia w danym wypadku. Decydujące znaczenie w tym względzie ma jednak nie tyle wyliczenie przewinień dyscyplinarnych, ile określenie ich treści. Należy bowiem zauważyć, że określenie niektórych z przewinień dyscyplinarnych zawiera zwroty o charakterze ocennym, niedookreślonym oraz otwartym (,inne"), które są niejako wpisane w ich naturę (przykłady w punktach 1, 4 i 11). Dotyczy to w szczególności zasad etycznych i wykonywania zawodu, które nie dają się ująć w ścisłe normy prawne. W przypadku komorników wynika to z faktu usytuowania ich w kręgu organów władzy publicznej ${ }^{8}$ oraz przewidzianej w art. 17 Konstytucji możliwości tworzenia samorządu zawodowego. Wskutek tego i konieczności prowadzenia działalności w sposób etyczny, prawidłowe wykonywanie zawodu komornika stwarza potrzebę kształtowania własnych, wewnątrzkorporacyjnych zasad działalności zawodowej. Posłużenie się przy definiowaniu przewinień dyscyplinarnych zwrotami o charakterze ocennym, niedookreślonym i otwartym stwarza jednak trudności w precyzyjnym wyznaczeniu granic odpowiedzialności dyscyplinarnej, w związku z czym może niekiedy stanowić podstawę do niebezpiecznego jej poszerzania. Ustalenie, czy i na ile postulat zamkniętego katalogu przewinień dyscyplinarnych - a w konsekwencji także realizacja standardów cechujących postępowania dyscyplinarne - został przez ustawodawcę w pełni

7 Druk nr 1582 Sejmu VIII kadencji.

8 Zob. art. 3 ust. 1 u.k.s. 
osiągnięty wymaga przybliżenia poszczególnych przewinień dyscyplinarnych zdefiniowanych w art. 222 u.k.s.

Katalog deliktów dyscyplinarnych komorników przewidziany w art. 222 u.k.s. można zasadniczo podzielić na dwie grupy. Pierwszą stanowi naruszenie powagi lub godności urzędu oraz uchybienie innym zasadom etyki zawodowej (pkt 1), drugą zaś przewinienia zawodowe, które można objąć ogólnym pojęciem naruszenia prawa (pkt 2-11). Przejdźmy zatem do przybliżenia poszczególnych przewinień dyscyplinarnych określonych w tym artykule.

Przewinienie dyscyplinarne w postaci naruszenia powagi i godności urzędu przewidziane w punkcie pierwszym uprzednio obowiązującego art. 71 u.k.s.e., zostało w art. 222 pkt 1 u.k.s. uzupełnione o, inne uchybienia zasadom etyki zawodowej”, a więc, jak należy wnosić, o naruszenia innych zasad etyki zawodowej niż powaga i godność urzędu. Rozróżnienie w art. 222 pkt 1 u.k.s. pojęć ,„powagi lub godności urzędu", nawiązujące do atrybutów komornika jako funkcjonariusza publicznego (art. 2 ust. 1 u.k.s.) pełniącego służbę na rzecz wymiaru sprawiedliwości, a więc działającego także w imieniu Rzeczypospolitej Polskiej ${ }^{9}$, zdaje się sugerować, że zawierają one odmienną treść. Nie wchodząc w ich szczegółową analizę, należy stwierdzić, że jeżeli nie pokrywają się w całości, to przynajmniej w znacznej części. Czyn naruszający powagę urzędu komornika może zatem stanowić jednocześnie naruszenie godności tego urzędu i odwrotnie. Tym niemniej, naruszenie powagi urzędu komornika będzie obejmowało naruszenia związane raczej z autorytetem komornika pełniącego służbę na rzecz wymiaru sprawiedliwości, natomiast naruszenie godności urzędu - działania nieetyczne, niemoralne, gorszące, naruszające dobre imię komornika w służbie i poza nią, w życiu społecznym, a nawet prywatnym ${ }^{10}$.

Ze względu na brak ustawowej definicji naruszenia powagi i godności urzędu komornika należy odwołać się w tym zakresie do wypowiedzi orzecznictwa i doktryny wskazujących przykładowe zachowania, które przynoszą ujmę powadze i godności urzędu. Mając na uwadze pełnione przez komornika funkcje na rzecz wymiaru sprawiedliwości, można przyjąć, że w odniesieniu do przewinień dyscyplinarnych polegających na naruszeniu powagi lub godności urzędu, aktualne będzie zasadniczo orzecznictwo dotyczące naruszenia godności urzędu przez sędziego. W wyroku z 20 września 2007 roku, SNO 60/0711, Sąd Najwyższy przyjął, że uchybia godności sędziego zachowanie polegające na zaciąganiu pożyczek, niespłacaniu ich i doprowadzeniu do przymusowej egzekucji, gdyż godzi w jego prestiż i podaje w wątpliwość nieskazitelność charakteru. Jako naruszenie godności urzędu sędziego zostało uznane także niezłożenie przez sędziego wniosku o wyłączenie z prowadzonego postępowania i podejmowanie czynności w warun-

9 M. Klonowski, op. cit., uw. 6 do art. 222.

10 Por. uzasadnienie do wyroku Sądu Najwyższego z 11 września 2007 roku, SNO 50/07, OSNSD 2007, poz. 70.

11 OSNSD $2007 \mathrm{nr}$ 1, poz. 12. 
kach konfliktu interesów ${ }^{12}$, nabycie nieruchomości na licytacji jako stanowiące naruszenie zakazu podejmowania działań finansowych, które mogą być odebrane jako wykorzystywanie jego pozycji zawodowej ${ }^{13}$. Z kolei w wyroku z 16 maja 2006 roku, SNO 19/06 ${ }^{14}$, Sąd Najwyższy uznał za przewinienie dyscyplinarne także czyn polegający na tym, że składając reklamację adresowaną do dyrektora spółki organizującej wyjazdy zagraniczne, sędzia użył pieczątki służbowej przewodniczącego wydziału, przez co wykorzystuje pełnioną funkcję do wsparcia swojej prywatnej sprawy.

Natomiast w doktrynie jako przykłady naruszenia przez komornika powagi lub godności urzędu wskazuje się udzielanie pożyczek na dużą skalę lub na lichwiarski procent; działalność polegającą na obrocie wierzytelnościami, gdyż działalność tego rodzaju może rodzić w ocenie społecznej uzasadnione podejrzenie, że przy odzyskiwaniu należnych wierzytelności komornik może dopuścić się nadużycia posiadanej pozycji; zachowania kontrowersyjne z punktu widzenia obyczajności, kwalifikujące się jako wykroczenie z art. 140 k.w.; pokazywanie się w stanie widocznego upojenia alkoholowego ${ }^{15}$, a niekiedy „,wprowadzenie się w stan nietrzeźwości”; stosowanie nieuczciwej konkurencji i niedopuszczalnej reklamy czy uchylanie się od obowiązku uczestnictwa w walnym zgromadzeniu izby komorniczej ${ }^{16}$. Przykładem naruszenia godności zawodu komornika może być także podjęcie dodatkowego zatrudnienia nielicującego z zajmowanym stanowiskiem funkcjonariusza publicznego, bo postrzeganego przez opinię publiczną jako ośmieszające lub niepoważne ${ }^{17}$.

Jak zostało zaznaczone, zawarte $\mathrm{w}$ art. 222 ust. 1 u.k.s sformułowanie, ,inne uchybienie zasadom etyki zawodowej”. ma na względzie innego rodzaju uchybienia zasadom etyki zawodowej komornika niż naruszenie powagi i godności urzę$\mathrm{du}^{18}$. Nasuwa się jednak pytanie, jakie działania lub zaniechania obejmuje swoim zakresem. Wydaje się, że rozwiązania tego problemu należy poszukiwać w postanowieniach Kodeksu Etyki Zawodowej Komornika Sądowego ${ }^{19}$, który już w preambule stanowi, że jest uchwalony w celu skonkretyzowania zasad wykonywania zawodu komornika, wyrażających się „,w szczególności” w obowiązkach: postępowania zgodnego z prawem i sumieniem, dochowania tajemnicy prawnie chronionej oraz kierowania się zasadami godności, honoru i uczciwości. Posłużenie

12 Wyrok Sądu Najwyższego z 24 listopada 2006 roku, SNO 64/06, LEX nr 470239.

13 Wyrok Sądu Najwyższego z 10 maja 2010 roku, SNO 26/07, LEX nr 568920.

14 OSNSD 2006, poz. 35.

15 M. Klonowski, op. cit.

16 A. Marciniak, op. cit., s. 289.

17 J. Jankowski, Odpowiedzialność dyscyplinarna komorników sądowych, [w:] Analiza i ocena ustawy o komornikach sądowych i egzekucji, red. K. Lubiński, Sopot 2000, s. 199.

18 Zgodnie z § 2 Kodeksu Etyki Zawodowej Komornika Sądowego, uchybienie zasadom etyki zawodowej komornika stanowi naruszenie powagi i godności urzędu rozumiane jako postępowanie sprzeczne z dobrem wymiaru sprawiedliwości.

19 Uchwała Krajowej Rady Komorniczej z 6 września 2016 roku, nr 1603/V ze zm. 
się w preambule Kodeksu zwrotem „W szczególności” oznacza jednak, że wskazanie w nim dyrektyw etycznego postępowania ma charakter przykładowy. To zaś prowadzi do wniosku, że pojęcie ,inne uchybienia zasadom etyki zawodowej”, którym posłużył się ustawodawca w art. 222 pkt 1 u.k.s. obejmuje swoim zakresem zasady etyki zawodowej sformułowane zarówno w Kodeksie Etyki Zawodowej Komornika Sądowego, jak i innego jeszcze rodzaju (pozakodeksowe).

Dlatego też należy przyjąć, że za przewinienia dyscyplinarne komornika określone $\mathrm{w}$ art. 222 pkt 1 u.k.s. może być uznane także zachowanie, które nie zostało określone w Kodeksie Etyki Zawodowej Komornika Sądowego, lecz nie zasługuje na aprobatę ze względu na jednoznacznie naganny moralnie charakter. Komornika jako funkcjonariusza publicznego obowiązują zatem wymagania stawiane zarówno wszystkim członkom społeczeństwa w zakresie przestrzegania zasad uznanych za powszechnie obowiązujące (jak zasady współżycia społecznego, dobre obyczaje, wykazywanie się rzetelnością i sumiennością, kierowanie się zasadami uczciwości oraz standardy wyższe), jak i wymagania wykraczające ponad minimum oczekiwane od ogółu (jak postawa godna i honorowa, postępowanie zgodne $\mathrm{z}$ własnym sumieniem oraz przestrzeganie obowiązków ściśle związanych z istotą wykonywanego zawodu, czyli postępowanie zgodne ze złożonym ślubowaniem, dochowanie tajemnicy prawnie chronionej, wykonywanie czynności zawodowych według najlepszej woli, wiedzy, w sposób bezstronny, ze szczególnym poszanowaniem praw i godności innych osób) ${ }^{20}$. Podwyższone standardy obowiązują komornika zarówno w związku z pełnieniem służby, jak i poza nią, gdyż uchybienie powagi i godności urzędu stanowi zachowanie naganne nie tylko publiczne, ale także wewnątrz środowiska komorniczego. Do znamion deliktu dyscyplinarnego komorników nie należy bowiem publiczny czy dostępny do powszechnej wiadomości sposób działania sprawcy ${ }^{21}$.

$\mathrm{Z}$ powyższych ustaleń wynika, że zakres działań lub zaniechań komornika sądowego, które na podstawie art. 222 pkt 1 u.k.s. mogą zostać uznane za przewinienie dyscyplinarne, nie jest zamknięty. Uzupełnienie treści tego przepisu w stosunku do brzmienia art. 71 u.k.s.c. poprzez dodanie ,inne uchybienia zasadom etyki zawodowej” ma więc zasadniczo charakter "doprecyzowujący”, a nie merytoryczny, gdyż w istocie nie zmienia zakresu tego przewinienia dyscyplinarnego. Należy jednak podkreślić, że ze względu na jego ocenny charakter, nie każde naruszenie powagi, godności lub inne uchybienie zasadom etyki zawodowej może stanowić przewinienie dyscyplinarne. Wskazał na to Sąd Najwyższy w uzasadnieniu wyroku z 11 września 2007 roku, SNO 50/07, stwierdzając, że nie każde naruszenie obowiązków służbowych stanowi jednocześnie uchybienie godności urzędu. Ocena w tym względzie należy zatem w pierwszej kolejności do organów dyscyplinarnych samorządu komorniczego (rzecznika dyscyplinarnego, komisji

20 Por. preambuła do Kodeksu Etyki Zawodowej Komornika Sądowego.

21 Por. wyrok Sądu Najwyższego z 30 sierpnia 2006 roku, SNO 36/06, OSNSD 2006, poz. 50. 
dyscyplinarnej), ostatecznie zaś do sądów apelacyjnych i Sądu Najwyższego rozpoznających środki zaskarżenia od orzeczeń komisji dyscyplinarnej.

Według art. 222 pkt 2 u.k.s. przewinieniem dyscyplinarnym komornika jest niewykonanie zaleceń powizytacyjnych, polustracyjnych lub pokontrolnych oraz zarządzeń organów nadzoru administracyjnego. Jest to rozwinięcie i uszczegółowienie przewinienia dyscyplinarnego przewidzianego $\mathrm{w}$ art. 71 pkt 3 u.k.s.e. (niewykonanie poleceń powizytacyjnych). W swej treści nawiązuje do nałożonego na komornika w art. 25 ust. 1 u.k.s. obowiązku postępowania zgodnie z zarządzeniami i zaleceniami wydawanymi przez organy nadzoru administracyjnego. Przewinienie to lokuje się zatem w kategorii przewinień służbowych związanych z niewykonaniem decyzji uprawnionych organów nadzoru, do których wydania przewidziana jest podstawa prawna w przepisach ustawy o komornikach, sam zaś obowiązek - określony w decyzjach (zaleceniach, zarządzeniach) właściwych organów. Nie obejmuje ono jednak swoim zakresem niewykonania przez komornika orzeczeń wydawanych w trybie nadzoru judykacyjnego, gdyż w tym przypadku będzie stanowiło przewinienie dyscyplinarne określone w art. 222 pkt 11 u.k.s. jako inna, rażąca lub uporczywa, obraza przepisów prawa.

$\mathrm{Z}$ art. 222 pkt 2 u.k.s. wynika, że delikt dyscyplinarny określony w tym przepisie obejmuje swoim zakresem zawinione niewykonanie wszystkich zaleceń, jakie mogą być wydane komornikowi przez organy nadzoru uprawnione do kontroli w różnych segmentach działalności komornika. Nasuwa się jednak pytanie, czy każde zawinione niewykonanie zaleceń i zarządzeń stanowi przewinienie dyscyplinarne. Na tak postawione pytanie należy udzielić odpowiedzi negatywnej. Pomocnymi w rozwiązaniu tego problemu mogą być przepisy Kodeksu karnego, do których odsyła art. 223 u.k.s., dotyczące wyłączenia odpowiedzialności karnej, czyli uznania, że w danych okolicznościach czyn nie stanowi przestępstwa, na przykład ze względu na znikomą społecznie szkodliwość czynu (art. 1 § 2 k.k.).

Zmianę co do typizacji przewinienia dyscyplinarnego należy odnotować również w odniesieniu do przewinienia polegającego na wydatkowaniu środków podlegających dokumentacji na działalność niezgodną z ich przeznaczeniem. Delikt ten przewidziany był również w u.k.s.e., w art. 71 pkt 4, z tym że w postaci kwalifikowanej, to jest gdy wydatkowanie środków podlegających dokumentacji było rażąco niezgodne z ich przeznaczeniem. Pominięcie w art. 222 pkt 3 u.k.s. słowa „rażąco” oznacza, że w obecnym stanie prawnym każdy przypadek wydatkowania środków podlegających dokumentacji na działalność niezgodną $\mathrm{z}$ ich przeznaczeniem może być oceniany jako przewinienie dyscyplinarne, a nie tylko taki, w ramach którego wydatkowanie jest „rażąco” niezgodne z przeznaczeniem środków. Zmiana ta $\mathrm{z}$ jednej strony usuwa problemy interpretacyjne wiążące się z rozumieniem wydatkowania środków rażąco niezgodnie $\mathrm{z}$ ich przeznaczeniem, $\mathrm{z}$ drugiej jednak rozszerza zakres odpowiedzialności dyscyplinarnej komornika. Jako przykłady takich przewinień wskazuje się w doktrynie zaniechanie obowiązku przekazania uprawnionemu wyegzekwowanych kwot (art. 31 u.k.s.), niezłożenie kwot niepod- 
legających wydaniu na rachunek depozytowy sądu (art. 808 k.p.c.), przeznaczenie pobranych zaliczek na wydatki niewymienione w art. 6 u.k.k., nieprawidłowości przy rozliczeniu pobranych zaliczek (art. 16 u.k.k.) czy też niezwrócenie otrzymanych od sądu rejonowego sum na pokrycie wydatków w sprawach osób zwolnionych od kosztów sądowych po ich wyegzekwowaniu (art. 17 u.k.k.), i inne ${ }^{22}$.

Nie ulega wątpliwości, że przewinienie dyscyplinarne wydatkowania środków podlegających dokumentacji na działalność niezgodną z ich przeznaczeniem może być popełnione przez komornika $\mathrm{z}$ winy umyślnej $\mathrm{w}$ zamiarze bezpośrednim. Wątpliwości nasuwa natomiast popełnienie tego deliktu w zamiarze ewentualnym, a już tym bardziej — $\mathrm{z}$ winy nieumyślnej. Wydatkowanie środków jest działaniem „kierunkowym”, zmierzającym do osiągnięcia założonego celu, a trudno byłoby przecież uznać, że wydatkując środki, czyli nie mając zamiaru wydatkowania ich niezgodnie z przeznaczeniem, komornik powinien lub mógł przewidywać, że na skutek niezachowania ostrożności zostaną one wydatkowane niezgodnie z przeznaczeniem. Dlatego też nie można postawić komornikowi zarzutu winy w wydatkowaniu środków podlegających dokumentacji niezgodnie z ich przeznaczeniem, jeżeli doszło do omyłkowego zaksięgowania sumy uzyskanej z egzekucji, omyłkowego wypłacenia należności innej osobie niż wierzyciel (innemu wierzycielowi o tym samym nazwisku i imieniu) itp., czyli upatrywać winy w tym, co nie było zamierzone.

Przewinieniem dyscyplinarnym przejętym bez żadnych zmian z poprzednio obowiązującego stanu prawnego (art. 71 pkt 5 u.k.s.e.) jest podejmowanie czynności z nieuzasadnioną zwłoką (art. 222 pkt 4 u.k.s.). Nie należy przez to rozumieć każdego podjęcia czynności ze zwłoką, lecz jedynie takie, gdy zwłoka jest przez komornika zawiniona. Może ona polegać zarówno na działaniu, jak i zaniechaniu, czyli nie tylko na dokonaniu przez komornika czynności ze zwłoką ale również na niedokonaniu czynności, której powinien był dokonać, a jednak jej poniechał, aczkolwiek w ostatnim przypadku zwłoka może stanowić również rażącą obrazę przepisów prawa przewidzianą $\mathrm{w}$ art. 222 pkt 11 u.k.s.

Zagadnienie, jakie wyłania się na gruncie tego przewinienia dyscyplinarnego, dotyczy przede wszystkim tych przypadków, gdy przepisy prawa przewidują dokonanie czynności przez komornika w terminie określonym w jednostkach czasu (dniach, tygodniach), na przykład w art. $767 \S 5$ k.p.c. (trzy dni) czy w art. 760 $\S 1^{1}$ k.p.c., zgodnie z którym komornik podejmuje niezbędne czynności niezwłocznie, nie później jednak niż w terminie siedmiu dni od dnia otrzymania wniosku. Problem dotyczy tego, czy dokonanie czynności z uchybieniem terminu wskazanego w jednostkach miary czasu, oznacza że czynność została podjęta z nieuzasadnioną zwłoką i w konsekwencji można poczynić zarzut winy w uchybieniu

22 A. Marciniak, op. cit., s. 291; M. Świeczkowska-Wójcikowska, op. cit., uw. 13 do art. 222 u.k.s.; B. Falkowski, [w:] Ustawa o komornikach sadowych. Ustawa o kosztach komorniczych. Komentarz, red. M. Simbierowicz, M. Świtkowski, Warszawa 2019, uw. 5 do art. 222. 
terminu. Odpowiedź na postawione pytanie musi być przecząca. Podjęcie przez komornika czynności po upływie ustawowego terminu nie oznacza, że można mu „automatycznie" przypisać winę uchybienia temu terminowi, przyczyny muszą bowiem być wynikiem zaniedbań komornika czy to $z$ winy umyślnej, czy nieumyślnej, gdyż tylko wtedy można uznać, że czynność została dokonana z nieuzasadnioną zwłoką. Dlatego też ocena tego, czy opóźnienie w dokonaniu (zaniechaniu) czynności było zawinione musi być dokonywana zawsze $\mathrm{z}$ uwzględnieniem charakteru czynności oraz całokształtu okoliczności danej sprawy.

Dla usunięcia ewentualnych nieporozumień zaznaczmy, że przewinienie dyscyplinarne, jakim jest podejmowanie czynności z nieuzasadnioną zwłoką, może być popełnione nie tylko wtedy, gdy przepisy ustawy przewidują określony w jednostkach czasu (dniach, tygodniach) termin dokonania (zaniechania) danej czynności. Może ono zostać popełnione również wtedy, gdy przepisy takiego terminu nie przewidują, komornik jest natomiast obwiązany podejmować czynności $\mathrm{z}$ urzędu. Takim przypadkiem - o znaczeniu doniosłym z praktycznego punktu widzenia - jest umorzenie postępowania egzekucyjnego z urzędu w razie zaistnienia przesłanek $\mathrm{z}$ art. $824 \S 1$ k.p.c., przewidziane w szeregu przepisów (na przykład w art. 820 k.p.c.) zawieszenie postępowania egzekucyjnego, podjęcie zawieszonego postępowania (art. $820^{2} \S 2$ k.p.c.) czy też złożenie wniosku przez komornika o wykreślenie z księgi wieczystej wniosku o wszczęcie egzekucji lub usunięcie takiego wniosku ze zbioru dokumentów (art. $924 \S 2$ k.p.c.).

Dla przypisania komornikowi zarzutu podejmowania czynności z nieuzasadnioną zwłoką nie jest wymagane uprzednie wydanie orzeczenia przez sąd na podstawie ustawy z 17 czerwca 2004 roku o skardze na naruszenie prawa strony do rozpoznania sprawy w postępowaniu przygotowawczym prowadzonym lub nadzorowanym przez prokuratora i postępowaniu sądowym bez nieuzasadnionej zwłoki ${ }^{23}$. Dlatego też ocena tego, czy doszło do popełnienia przez komornika czynu stanowiącego przewinienie w postaci podjęcia czynności z nieuzasadnioną zwłoką, musi być dokonywana w postępowaniu dyscyplinarnym samodzielnie, niezależnie od ewentualnych ustaleń $\mathrm{w}$ innym postępowaniu, $\mathrm{w}$ tym również toczącym się na podstawie ustawy z 17 czerwca 2004 roku $^{24}$.

Przewinienie dyscyplinarne komornika stanowi naruszenie przepisów o właściwości określonej w art. 9 i 10 u.k.s. (art. 222 pkt 5 u.k.s.). Również ten delikt jest przejęty zasadniczo z ustawy o komornikach sądowych i egzekucji z 29 lipca 1997 roku (art. 71 pkt 6), z tym że został nieco doprecyzowany poprzez objęcie nim - oprócz odmowy przyjęcia wniosku o wszczęcie egzekucji i wykonania postanowienia o udzieleniu zabezpieczenia — także innych czynności, do podjęcia których jest właściwy na postawie przepisów ustawy. W sposób szczególny ustawodawca zwrócił uwagę na naruszenie zasad przyjmowania spraw z wyboru

23 Dz.U. z 2018 r. poz. 75 ze zm.

24 Por. M. Klonowski, op. cit., uw. 10 do art. 222. 
wierzyciela. Naruszenie właściwości miejscowej wynikające z art. 10 u.k.s. (z wyboru wierzyciela) może polegać na przyjęciu sprawy spoza obszaru właściwości sądu apelacyjnego, na którym znajduje się siedziba kancelarii komornika (ust. 1 in principio), przyjęciu sprawy w przypadku, gdy ustawa nie daje wierzycielowi możliwości wyboru komornika spoza rewiru komorniczego (ust. 1 pkt 1-5), przyjęciu sprawy z wyboru wierzyciela przy jednoczesnym przekroczeniu limitów, o których mowa w ust. 4 art. 10 u.k.s., nieprzekazaniu sprawy innemu komornikowi na wniosek wierzyciela (ust. 9) oraz zaniechaniu przekazania sprawy komornikowi właściwemu w przypadku, gdy dopiero po wszczęciu postępowania, w wyniku czynności sprawdzających, okaże się, że zachodziła pierwotna niewłaściwość komornika (ust. 10).

Przewinienie dyscyplinarne przewidziane w art. 222 pkt 5 u.k.s. może zatem polegać także na odmowie wykonania postanowienia o zabezpieczeniu spadku i sporządzenia spisu inwentarza oraz czynności wymienionych w art. 3 ust. 4 pkt 1 i 2 u.k.s. (dokonanie doręczeń, sporządzenie protokołu stanu faktycznego), jeżeli zostały zlecone przez sąd, prokuratora albo osobę zobowiązaną do złożenia wniosku. Wątpliwości może budzić pominięcie w art. 9 ust. 2 u.k.s. uregulowania art. 3 ust. 4 pkt 1a u.k.s., czyli podjęcia czynności zmierzających do ustalenia aktualnego miejsca zamieszkania adresata. Jest to tym bardziej zaskakujące, że tą samą ustawą, to jest z 4 lipca 2019 roku o zmianie Kodeksu postępowania cywilnego ${ }^{25}$, został znowelizowany przepis art. 9 ust. 2 u.k.s. zawierający odesłanie do art. 3 ust. 4 pkt 1 i 2 oraz dodany art. 3 ust. 4 pkt 1a. Mając na uwadze, że komornik może ponosić odpowiedzialność dyscyplinarną tylko za działania zawinione i zaniechania stypizowane $\mathrm{w}$ ustawie, można próbować obrony poglądu, że odmowa przyjęcia zlecenia podjęcia czynności określonych w art. 3 ust. 4 pkt 1a u.k.s. (zmierzających do ustalenia aktualnego miejsca zamieszkania adresata) nie stanowi przewinienia dyscyplinarnego. Pogląd ten wydaje się jednak nieuzasadniony ze względu na treść art. 222 pkt 11 u.k.s., według którego przewinieniem dyscyplinarnym jest inna niż wymieniona w pkt $1-10$, a więc i w punkcie piątym, rażąca obraza przepisów prawa, a takim przewinieniem jest odmowa dokonania przez komornika czynności, do której obowiązany jest na podstawie przepisów ustawy. Jeśli nawet przyjąć, że odmowa podjęcia czynności zmierzających do ustalenia aktualnego miejsca zamieszkania adresata, a zleconych przez sąd albo powoda zobowiązanego przez sąd na podstawie art. $139^{1} \S 1$ k.p.c., nie stanowi przewinienia dyscyplinarnego z art. 222 pkt 5 u.k.s., to stanowić będzie przewinienie przewidziane w punkcie 11 tego artykułu.

Nowym przewinieniem dyscyplinarnym, nieznanym ustawie o komornikach sądowych i egzekucji z 29 sierpnia 1997 roku, jest niepodjęcie lub nieterminowe podjęcie czynności z art. $767 \S 5$ k.p.c. (art. 222 pkt 6 u.k.s.). Jest ono następstwem zmiany trybu zaskarżania czynności komornika dokonanej ustawą z 15 lipca 2015

25 Dz.U. z 2019 r. poz. 1469 ze zm. 
roku o zmianie ustawy — Kodeks cywilny, ustawy — Kodeks postępowania cywilnego i niektórych innych ustaw ${ }^{26}$. W następstwie tej zmiany skarga jest wnoszona do sądu rejonowego za pośrednictwem komornika, a nie jak wcześniej, bezpośrednio do sądu. Jak się wskazuje w doktrynie, ma to na celu wyeliminowanie niepożądanych sytuacji, w których komornik przetrzymywałby złożoną skargę pomimo jej nieuwzględnienia na podstawie art. $767 \S 5$ k.p.c., celem uniemożliwienia lub utrudnienia rozpatrzenia jej przez sąd ${ }^{27}$.

W przypadku tego deliktu dyscyplinarnego na uwagę zasługuje zbyt kategoryczne sformułowanie przepisu art. 222 pkt 5 u.k.s. i zbyt krótki termin (trzy dni), w którym komornik ma obowiązek dokonania czynności wymienionych w art. $767 \S 5$ k.p.c. Z brzemienia art. 222 pkt 5 u.k.s. zdaje się bowiem wynikać, że przewinienie dyscyplinarne stanowi każde naruszenie terminu $\mathrm{z}$ art. $767 \S 5$ k.p.c. (trzy dni), tymczasem jednak nie ulega wątpliwości, że zachowanie tego terminu może być niekiedy trudne, a nawet niemożliwe, zwłaszcza w przypadku konieczności sporządzenia uzasadnienia zaskarżonej czynności, o ile wcześniej nie było sporządzone, w sprawach skomplikowanych i w związku ze sformułowaniem przez skarżącego szeregu zarzutów. Skoro zgodnie z art. 222 u.k.s. in principio, przewinieniem dyscyplinarnym może być działanie lub zaniechanie zawinione, to skłania do wniosku, że nie każde nieterminowe podjęcie przez komornika czynności z art. $767 \S 5$ k.p.c. (z przekroczeniem terminu trzech dni) może być uznane za przewinienie dyscyplinarne $\mathrm{z}$ tej przyczyny. W tym kontekście należy odnieść się krytycznie zarówno do zbyt krótkiego terminu (trzy dni), w jakim czynności według art. $767 \S 5$ k.p.c. powinny być podjęte przez komornika, jak i do potrzeby wprowadzenia tego deliktu dyscyplinarnego w art. 222 u.k.s. Wydaje się że $\mathrm{w}$ takich przypadkach $\mathrm{w}$ celu pociągnięcia komornika do odpowiedzialności wystarczające byłoby uregulowanie art. 222 pkt 4 u.k.s., które w sposób ogólny penalizuje podejmowanie przez komornika czynności z nieuzasadnioną zwłoką.

Nowym przewinieniem dyscyplinarnym wprowadzonym ustawą o komornikach sądowych jest brak nadzoru nad zatrudnionymi asesorami i aplikantami oraz innymi osobami, o których mowa w art. 153 ust. 1 u.k.s. Powinność ta wynika ze szczególnego obowiązku, jaki nakłada na komornika art. 153 ust. 5 u.k.s., to znaczy bieżącego kontrolowania prawidłowości wykonywania przez pracowników i współpracowników powierzonych im zadań, czego skutkiem ma być wyeliminowanie wszelkich błędów i nieprawidłowości poczynionych przez te osoby. Wydaje się, że podniesienie obowiązku nadzoru, a właściwie jego braku, do rangi przewinienia dyscyplinarnego ma przymusić komornika do większej aktywności w tym zakresie. Odpowiedzialność komornika jest oczywiście wyłączona w przy-

26 Dz.U. z 2015 r. poz. 1311 ze zm.

27 M. Klonowski, op. cit., uw. 12 do art. 222. 
padku, gdy nie przewidział i nie mógł przewidzieć zachowania podległych mu osób, a tym samym zapobiec tak im, jak i ich skutkom.

Nowym rodzajem przewinienia dyscyplinarnego jest także pozyskiwanie przez komornika informacji z naruszeniem art. $761 \S 1$ k.p.c. (art. 222 pkt 8 u.k.s.). Wprowadzenie tego przewinienia jest konsekwencją pozyskiwania przez niektórych komorników informacji z naruszeniem art. 761 § 1 k.p.c. w jego ówczesnym brzmieniu oraz przekazywanie ich osobom postronnym. Informacje te były pozyskiwane, gromadzone, przetwarzane, a nawet udostępniane wierzycielom, także potencjalnym, oraz innym osobom i w innym celu niż na potrzeby prowadzonego postępowania egzekucyjnego ${ }^{28}$. Jednak stypizowanie pozyskiwania przez komornika informacji z naruszeniem art. $761 \S 1$ k.p.c. jako przewinienia dyscyplinarnego wymaga chociażby przybliżenia, w jakim zakresie komornik może żądać informacji na podstawie tego przepisu, aby nie narazić się na zarzut popełnienia przewinienia dyscyplinarnego.

Powołując się na art. 761 k.p.c., komornik może pozyskiwać od uczestników postępowania informacje $\mathrm{w}$ zakresie niezbędnym do zapewnienia prawidłowego wykonania zadań określonych w art. 3 ust. 3 u.k.s., a więc nie tylko dla potrzeb prowadzonych postępowań egzekucyjnych i zabezpieczających. Jednak nie mogą to być wiadomości pozyskiwane w innych celach i wykraczające poza te zadania, dlatego też informacje, które mają być udzielone, powinny być jasno sprecyzowane. W przypadku postępowania egzekucyjnego lub zabezpieczającego mogą dotyczyć majątku i dochodów dłużnika w zakresie, w jakim jest to niezbędne do wykonania obowiązku stwierdzonego tytułem wykonawczym. Komornik nie może zatem ustalać całego majątku dłużnika, jeżeli nie jest to niezbędne dla osiągnięcia celu egzekucji lub wykonania zabezpieczenia, jak również szacować majątku dłużnika na wniosek wierzyciela, nawet dysponującego tytułem wykonawczym przeciwko dłużnikowi, który dopiero zamierza wszcząć postępowanie egzekucyjne. Nie może również ustalać danych dotyczących osoby dłużnika oraz innych osób, w tym spadkobierców zmarłego dłużnika, przede wszystkim numeru PESEL $i$ innych danych, na przykład miejsca zamieszkania, stanu rodzinnego. Trafne jest w tym względzie stanowisko Sądu Okręgowego w Warszawie wyrażone w wyroku z 16 czerwca 2011 roku, V CZ 1883/1129, że informacje żądane przez komornika muszą być nie tylko niezbędne do prawidłowego przebiegu egzekucji, ale nie mogą także wykraczać poza zakres wyznaczony sposobem egzekucji wskazanym przez wierzyciela.

Nowym rodzajem przewinienia dyscyplinarnego jest również naruszenie przez komornika zasad korzystania z prawa do nieobecności oraz usprawiedliwiania tych nieobecności (art. 222 pkt 9 u.k.s.). Przewinienie to nawiązuje do uregulowania w ustawie o komornikach sądowych nieobecności komornika na służbie,

28 Por. M. Klonowski, op. cit., uw. 14 do art. 222.

29 „Monitor Prawa Bankowego” 2013, nr 11, poz. 11-12. 
usprawiedliwiania tych nieobecności oraz korzystania z wyznaczonego zastępcy, ściśle określonych $\mathrm{w}$ art. 39-41 i art. 43. Ponieważ komornik zgodnie z przyjętymi założeniami ma wykonywać powierzone mu zadania zasadniczo osobiście (art. 3 ust. 2 u.k.s.), przepisy regulujące sytuacje, w których nie pełni on służby, zostały skonstruowane na podobieństwo regulacji pracowniczych. Wskazują na to wprost art. 39 ust. $1 \mathrm{zd} .2$ oraz art. 41 ust. 3 u.k.s., odsyłając w tym zakresie do odpowiedniego stosowania przepisów Kodeksu pracy, o ile nie są one sprzeczne z przepisami regulującymi pełnienie służby przez komornika. W zakresie sposobu i przyczyn usprawiedliwiania nieobecności będą miały zatem zastosowanie przepisy rozporządzenia Ministra Pracy i Polityki Socjalnej z 15 maja 1996 roku w sprawie sposobu usprawiedliwiania nieobecności w pracy oraz udzielania pracownikom zwolnień od pracy ${ }^{30}$. Uprawnienia w zakresie kontroli przestrzegania przez komornika zasad korzystania z prawa do nieobecności, usprawiedliwiania tych nieobecności oraz korzystania z wyznaczonego zastępcy określonych $\mathrm{w}$ art. 39-41 i art. 43 u.k.s., zostały powierzone prezesowi sądu rejonowego, przy którym działa komornik.

Przepis art. 222 pkt 9 u.k.s. nie wymaga, aby naruszenie obowiązków komornika w zakresie zasad korzystania z prawa do nieobecności, usprawiedliwiania tych nieobecności było rażące lub uporczywe. Unormowanie to wskazuje, że zasadniczo każde zawinione naruszenie, a więc również to mniejszej wagi, może stanowić przesłankę do pociągnięcia komornika do odpowiedzialności dyscyplinarnej. Naruszenie zasad korzystania z nieobecności, usprawiedliwiania tych nieobecności albo korzystania z wyznaczonego zastępcy komornika może przybrać różne formy i polegać na niezgłoszeniu nieobecności na służbie prezesowi właściwego sądu rejonowego, korzystaniu z nieobecności na służbie po wykorzystania prawa do wypoczynku, wprowadzeniu prezesa sądu rejonowego w błąd co do okoliczności uzasadniających nieobecność czy wreszcie wskazywaniu zastępcy z naruszeniem przepisów określających zasady jego wyznaczania ${ }^{31}$. Uporczywe lub rażące naruszenie tych obowiązków stanowi również samoistną podstawę do odwołania komornika z zajmowanego stanowiska przez Ministra Sprawiedliwości na wniosek prezesa właściwego sądu na podstawie art. 19 ust. 2 pkt 7 u.k.s.

Przewinieniem dyscyplinarnym nieznanym na gruncie ustawy o komornikach sądowych i egzekucji z 1997 roku jest również odmowa podjęcia przez komornika obowiązków zastępcy komornika (art. 222 ust. 10 u.k.s.). Przewinienie to obejmuje odmowę podjęcia obowiązków zastępcy komornika przez zastępcę ustanowionego albo z inicjatywy prezesa sądu rejonowego albo apelacyjnego w przypadku przewidzianym w art. 43 ust. 6 u.k.s., albo przez prezesa sądu apelacyjnego w przypadku przewidzianym w art. 45 ust. 5 u.k.s., a nie na skutek wskazania przez komornika (art. 43 ust. 6 u.k.s.) albo radę właściwą izby komorniczej (45 ust. 5 u.k.s.).

30 Dz.U. z 2014 r. poz. 1632.

31 M. Klonowski, op. cit., uw. 15 do art. 222. 
Według literalnego brzmienia art. 222 pkt 11 u.k.s., przewinieniem dyscyplinarnym są także zawinione działania lub zaniechania komornika inne niż wymienione w przepisach punktów 1-10 tego artykułu, stanowiące rażącą lub uporczywą obrazę przepisów prawa. Posłużenie się w tym przepisie przez ustawodawcę otwartą, niedookreśloną formułą obrazy przepisów prawa (,inną”) wynika z faktu, że na komorniku sądowym jako na funkcjonariuszu publicznym spoczywa szczególny obowiązek postępowania zgodnie zasadami etyki i z przepisami prawa, orzeczeniami, zarządzeniami, zaleceniami organów uprawnionych do nadzoru (art. 25 ust. u.k.s.). Problemy interpretacyjne przy definiowaniu tego przewinienia dyscyplinarnego sprawia posłużenie się przez ustawodawcę określeniami „rażąca” lub ,uporczywa” przy regulowaniu obrazy przepisów prawa. Trudności wywołuje nie tylko brak definicji legalnej tych pojęć, ale również ich wzajemnej relacji. Poczynając od drugiej kwestii, wydaje się, że pomiędzy rażącą i uporczywą obrazą przepisów prawa zachodzi relacja krzyżowania, a nie pokrywania się. Rażąca obraza przepisów prawa może bowiem być także uporczywa, jeżeli będzie miała charakter powtarzalny, z kolei uporczywa może być także rażąca, jeżeli będzie trwała przez dłuższy czas i będzie dokonywana ze złej woli nieprzestrzegania obowiązujących przepisów. Różnica polega na tym, że „rażąca” obraza przepisów prawa może ograniczyć się do jednego czynu, podczas gdy „uporczywa” wymaga dla swojego bytu wielokrotnego działania, na przykład w warunkach czynu ciągłego o mniejszym ciężarze gatunkowym, czyli nie musi być rażącym, lecz „Zwykłym” naruszeniem prawa.

Przechodząc do zdefiniowania tych pojęć, należy wskazać, że posłużenie się przez ustawodawcę w art. 222 pkt 11 u.k.s. pojęciem rażącej obrazy prawa oznacza, że chodzi o obrazę nie tylko jasną, bezsporną, łatwą do stwierdzenia na pierwszy rzut oka, ale konieczne jest ponadto uwzględnienie kwalifikowanego charakteru tego naruszenia, czyli „ciężaru gatunkowego”, który świadczy o powadze uchybienia, jego doniosłości ze społecznego i indywidualnego punktu widzenia (stron) ${ }^{32}$, oraz o złej woli naruszającego. Stąd też ocena tego, czy mamy do czynienia z rażącą lub uporczywą obrazą przepisów prawa, musi być dokonywana z uwzględnieniem całokształtu okoliczności konkretnej sprawy ${ }^{33}$.

Ze względu na ocenny charakter pojęcie „rażącej” obrazy przepisów prawa doczekało się bogatego orzecznictwa przede wszystkim na gruncie postępowań dyscyplinarnych prowadzonych przeciwko sędziom. Orzecznictwo nie zmierza jednak do sformułowania definicji o charakterze ogólnym, lecz precyzuje to pojęcie na gruncie i dla potrzeb określonych stanów faktycznych. Tak więc w wyroku z 22 października 1987 roku, III CRN 314/8734, Sąd Najwyższy przyjął, że rażące naruszenie prawa jest wyrazem ewidentnego i jasno uchwytnego błędu w interpre-

32 M. Świeczkowska-Wójcikowska, op. cit., uw. 23 do art. 222.

33 Por. wyrok Sądu Najwyższego z 13 września 2011 roku, SNO 34/11, Legalis nr 461888; wyrok Sądu Najwyższego z 10 stycznia 2013 roku, II K 32/09, LEX nr 1296711.

34 OSPiKA $1989 \mathrm{nr}$ 1, poz. 12. 
towaniu prawa. Jeśli jednak przepis dopuszcza rozbieżną interpretację, w konkretnych wypadkach nawet mniej lub bardziej uzasadnioną, to wybór jednej z takich interpretacji, jeżeli zostanie potem uznany za nieprawidłowy, nie może być oceniany jako rażące naruszenie prawa. Chodzi więc raczej o stwierdzenie ewidentnego błędu, nie zaś o wybór jednej z możliwych do przyjęcia interpretacji. Naruszenie prawa o rażącym charakterze występuje przede wszystkim wówczas, gdy treść rozstrzygnięcia pozostaje $\mathrm{w}$ wyraźnej i oczywistej sprzeczności $\mathrm{z}$ treścią przepisów prawa i gdy charakter tego naruszenia powoduje, że rozstrzygnięcie nie może być zaakceptowane jako akt wydany przez organ praworządnego państwa.

Patrząc z przez pryzmat deliktu dyscyplinarnego rażącej obrazy przepisów prawa, na szczególną uwagę zasługuje kwestia stosowania się do wytycznych sądu uwzględniającego środek zaskarżenia i przekazującego sprawę do ponownego rozpoznania oraz zarządzeń wydanych w trybie nadzoru, na przykład na podstawie art. 759 § 2 k.p.c. oraz aktualnego orzecznictwa sądów, zwłaszcza Sądu Najwyższego. Nie powinno raczej budzić wątpliwości, że działania komornika w tych okolicznościach będą co do zasady oceniane z perspektywy przewinienia dyscyplinarnego. O rażącej obrazie przepisów prawa przez komornika, który nie zastosował się do wytycznych albo orzecznictwa, może być jednak mowa jedynie wtedy, gdy orzecznictwo w danym przypadku jest jednoznaczne i nie budzi wątpliwości. W przeciwnym przypadku trudno uznać, aby przyjęcie jednej z możliwych interpretacji przepisów prawa, poparte wywodami prawidłowymi z prawnego i logicznego punktu widzenia, mogło stanowić nie tylko rażącą, ale w ogóle obrazę przepisów prawa, nawet gdy określony kierunek wykładni został zawarty w wytycznych sądu przekazującego sprawę do ponownego rozpoznania albo w zarządzeniach wydanych w trybie nadzoru, na przykład na podstawie art. 759 $\S 2$ k.p.c., chociaż przepis ten stanowi, że ocena prawna wyrażona przez sąd w ramach wydanych zarządzeń jest dla komornika wiążąca. Rozbieżności orzecznictwa uzasadniają bowiem tezę, że dany przepis nie jest „oczywisty”, a nie popełnia przewinienia dyscyplinarnego komornik stosujący się do wytycznych i oceny sądu sprawującego nad nim nadzór judykacyjny, nawet jeśli w świetle dominujących w orzecznictwie poglądów wykładnia ta jest błędna.

Pojęcie „uporczywości” użyte przez ustawodawcę w art. 222 pkt 11 u.k.s., podobnie jak określenie „rażące”, jest niedookreślone. W języku potocznym rozumiane jest jako coś trudnego do usunięcia, utrzymujące się długo lub ciągle powtarzające ${ }^{35}$. Przenosząc ów termin na grunt prawa, można przyjąć, że oznacza wielokrotne uchybienie, zachowanie o charakterze trwałym albo powtarzającym się mimo realnej możliwości zachowania się zgodnie z obowiązującymi przepisami prawa. W literaturze wskazuje się ponadto, że działanie to powinno być nacechowane złą wolą przejawiającą się celowym nieprzestrzeganiem obowiązu-

35 Zob. Maty Stownik Języka Polskiego, Warszawa 1994, s. 984. 
jącego prawa ${ }^{36}$. W tym przypadku wystarczy jednak ,zwykła” obraza przepisów prawa, o mniejszym ciężarze gatunkowym, charakteryzująca się ciągłością lub powtarzalnością, a nie „rażąca”, która trwa lub powtarza się przez pewien czas, charakteryzując się przy tym świadomą uporczywością (konsekwencją) w dokonywaniu naruszeń mimo realnej możliwości zachowania się zgodnie z prawem ${ }^{37}$.

Analiza przewinień dyscyplinarnych komornika określonych w art. 222 u.k.s., chociaż niewyczerpująca ze względu na wymagania redakcyjne, wskazuje, że przyjęte przez ustawodawcę założenie zamkniętego katalogu przewinień dyscyplinarnych nie zostało w pełni zrealizowane. Wyczerpujące wyliczenie przewinień dyscyplinarnych $\mathrm{w}$ art. 222 u.k.s. i posłużenie się przez ustawodawcę w tym przepisie zwrotem „za następujące” zamiast „,W szczególności” nie przesądza bowiem w sposób jednoznaczny o możliwości pociągnięcia komornika do odpowiedzialności dyscyplinarnej za działania lub zaniechania ściśle określone. Niektóre z przewinień wymienionych $\mathrm{w}$ art. 222 u.k.s. są bowiem, jak zostało wyżej wykazane, tak określone, by wskazywały na możliwość pociągnięcia komornika do odpowiedzialności dyscyplinarnej za każde zawinione działanie lub zaniechanie. Jako przykład wystarczy podać chociażby niewykonanie zaleceń powizytacyjnych, polustracyjnych, pokontrolnych organów nadzoru judykacyjnego (pkt 2), wydatkowanie środków podlegających dokumentacji na działalność niezgodną z ich przeznaczeniem (pkt 3) czy brak nadzoru nad zatrudnionymi asesorami, aplikantami oraz innymi osobami podlegającymi nadzorowi komornika (pkt 7). Z analogiczną sytuacją mamy do czynienia w grupie przewinień dyscyplinarnych określonych przy użyciu zwrotów ocennych, niedookreślonych i otwartych, zwłaszcza w punktach 1, 4 i 11 art. 222 u.k.s. Co więcej, można zaryzykować twierdzenie, że wskutek dodania do art. 222 u.k.s. przewinień dyscyplinarnych nowych $\mathrm{w}$ stosunku do wymienionych w art. 71 u.k.s.e. ich zakres został rozszerzony w stosunku do poprzednio obowiązującego. Mimo że art. 222 u.k.s. wylicza przewinienia dyscyplinarne w sposób zamknięty, co sugeruje że komornik może być pociągnięty do odpowiedzialności dyscyplinarnej za zawinione działanie i zaniechanie wchodzące $\mathrm{w}$ zakres jednego z nich, to w rzeczywistości obszary zawinionego działania lub zaniechania komornika, za które nie może być pociągnięty do odpowiedzialności, są niewielkie. Nawet zawinione działania lub zaniechania innego rodzaju niż naruszenie powagi lub godności urzędu oraz rażąca lub uporczywa obraza przepisów prawa, mogą być w znacznej części „podciągnięte” pod inne uchybienia zasadom etyki zawodowej. W związku z powyższym wydaje się, że katalog przewinień dyscyplinarnych, mimo dość istotnej zmiany treści art. 222 u.k.s. w relacji do art. 71 u.k.s.e., nadal nie jest zamknięty ${ }^{38}$, wbrew spotykanym niekiedy w doktrynie poglądom ${ }^{39}$.

36 M. Świeczkowska-Wójcikowska, op. cit., uw. 23 do art. 222.

37 Zob. B. Falkowski, op. cit., uw. 13 do art. 222.

38 Ibidem, uw. 2 do art. 222.

${ }^{39}$ M. Klonowski, op. cit., uw. 3 do art. 22; M. Świeczkowska-Wójcikowska, op. cit., uw. 4 do art. 222 . 
Nie oznacza to jednak, że każde zawinione działanie i zaniechanie komornika, które mieści się w zakresie pojęciowym art. 222 u.k.s., stanowi przewinienie dyscyplinarne, za które komornik może być pociągnięty do odpowiedzialności. Za przewinienie dyscyplinarne może bowiem zostać uznane naruszenie zasad etyki zawodowej komornika oraz obraza przepisów prawa, które są na tyle istotne, że nie mogą być akceptowane w środowisku zawodowym komorników oraz poza nim. Prowadzi to do wniosku, że nie za każde naruszenie zasad etyki zawodowej lub obrazę przepisów prawa komornik może być pociągnięty do odpowiedzialności dyscyplinarnej. Wskazał na to wyraźnie Sąd Najwyższy we wspomnianym już uzasadnieniu wyroku z 11 września 2007 roku, SNO 50/97, przyjmując, że nie każde naruszenie obowiązków służbowych stanowi jednocześnie uchybienie godności urzędu ${ }^{40}$. Doniosła rola $w$ tym zakresie przypada zatem organom właściwym w sprawach dyscyplinarnych (wnioskodawcom składającym wniosek o wszczęcie postępowania dyscyplinarnego, oskarżycielowi, komisji dyscyplinarnej) oraz sądom rozpoznającym środki zaskarżenia od orzeczeń komisji dyscyplinarnej. Organy te powinny dokonać rzetelnej oceny tego, czy naruszenie przez komornika zasad etyki zawodowej lub przepisów prawa jest na tyle istotne, że nie może być akceptowane ze społecznego i indywidualnego punktu widzenia ze względu na funkcję pełnioną przez komornika dla potrzeb wymiaru sprawiedliwości . Organy właściwe $\mathrm{w}$ sprawach dyscyplinarnych komorników powinny mieć zatem na uwadze, aby z jednej strony nie wszczynać postępowań i nie karać komorników za działania lub zaniechania wprawdzie zawinione, ale błahe, których społeczna szkodliwość jest znikoma (art. $1 \S 2$ k.k. w zw. z art. 223 u.k.s.), z drugiej zaś aby nie pozostały bezkarne działania lub zaniechania komorników nieakceptowalne w odczuciu społecznym ze względów prawnych lub etycznych.

$\mathrm{Na}$ marginesie tych uwag należy zaznaczyć, że wyliczenie w art. 222 u.k.s. katalogu przewinień dyscyplinarnych razi nadmierną kazuistyką oraz zbędnością. Niektóre z nich, dodane pod wpływem orzecznictwa sądów dyscyplinarnych, wykazują się charakterem szczegółowym czy wręcz jednostkowym, objęte są bowiem zakresem innych regulacji o charakterze ogólnym. W rachubę wchodzą chociażby przewinienie określone w punkcie 6 (niepodjęcie i nieterminowe podjęcie czynności, o których mowa w art. $767 \S 5$ k.p.c., a które podpada również pod przewinienie podejmowania czynności z nieuzasadnioną zwłoką z punktu 4), 5 (naruszenie przepisów o właściwości miejscowej), 8 (pozyskiwanie wiadomości z naruszeniem art. 767 § 1 k.p.c.), 9 (naruszenie zasad korzystania z nieobecności) czy 10 (odmowa podjęcia obowiązków zastępcy komornika), które stanowią niewątpliwie rażącą obrazę przepisów prawa (pkt 11).

40 OSNSD 2007, poz. 70. 


\section{DISCIPLINARY OFFENCES OF COURT ENFORCEMENT OFFICERS}

\section{Summary}

Disciplinary offences of court enforcement officers are exhaustively listed in Art. 222 of the Act on Court Enforcement Officers dated 22 March 2018 (consolidated text: Journal of Laws of 2020 item 121 as amended). The article analyses the question whether the catalogue of culpable actions and omissions of the court enforcement officer listed in that provision, for which he/she may be held liable under a disciplinary procedure, is exhaustive or open-ended. To this end, particular disciplinary offences enumerated in Art. 222 of the Act on Court Enforcement Officers have been examined. The findings made lead to the conclusion that despite disciplinary offences are exhaustively listed, the catalogue of culpable actions and omissions, for which the court enforcement officer may be responsible under a disciplinary procedure, is open-ended, since no activities of the officer have been precisely defined which could be deemed disciplinary offences.

Keywords: disciplinary offence, catalogue of disciplinary offences, infringement of the professional ethics of the court enforcement officer, breach of law, flagrant or persistent breach of law

\section{BIBLIOGRAFIA}

Falkowski B., [w:] Ustawa o komornikach sadowych. Ustawa o kosztach komorniczych. Komentarz, red. M. Simbierowicz, M. Świtkowski, Warszawa 2019.

Jagieła J., Odpowiedzialność dyscyplinarna komorników, asesorów i aplikantów komorniczych, [w:] Zatożenia projektu nowej ustawy o komornikach sąowych, red. A. Marciniak, Sopot 2013.

Jankowski J., Odpowiedzialność dyscyplinarna komorników sądowych, [w:] Analiza i ocena ustawy o komornikach sadowych i egzekucji, red. K. Lubiński, Sopot 2000.

Klonowski M., [w:] Ustawa o komornikach sadowych. Ustawa o kosztach komorniczych. Komentarz, red. R. Reiwer, Warszawa 2019.

Knypl Z., Merchel Z., Komentarz do ustawy o komornikach sąowych i egzekucji, Sopot 2013.

Kuczyński G., [w:] Ustawa o komornikach sądowych i egzekucji. Komentarz, red. J. Świeczkowski, Warszawa 2012.

Maty Stownik Języka Polskiego, Warszawa 1994.

Marciniak A., Ustawa o komornikach sądowych i egzekucji. Komentarz, Warszawa 2009.

Rączka P., Odpowiedzialność dyscyplinarna komornika sądowego, „Przegląd Prawa Egzekucyjnego" 2006, nr 12.

Świeczkowska-Wójcikowska M., [w:] Ustawa o komornikach sądowych. Ustawa o kosztach komorniczych. Kodeks Etyki Zawodowej Komornika Sadowego. Komentarz, red. M. Świeczkowska-Wójcikowska, J. Świeczkowski, Warszawa 2020. 